\title{
Genetic variability in a narrow endemic snapdragon (Antirrhinum subbaeticum, Scrophulariaceae) using RAPD markers
}

\author{
JF Jiménez ${ }^{1}$, P Sánchez-Gómez ${ }^{1}$, J Güemes², O Werner ${ }^{1}$ and JA Rosselló ${ }^{2}$ \\ ${ }^{1}$ Departamento de Biología Vegetal (Botánica), Universidad de Murcia, Campus de Espinardo, E-30100, Murcia, Spain; ${ }^{2} J a r d i n$ \\ Botánico, Universidad de Valencia, c/Quart 80, E-46008, Valencia, Spain
}

\begin{abstract}
Antirrhinum subbaeticum is an endangered species inhabiting fragmented limestone cliffs. In the last 3 years, a drastic population decline has been observed in three of four known populations and the estimated number of surviving individuals is now close to 400. A RAPD study was conducted to evaluate the levels of genetic variation present in this species to improve conservation guidelines. Thity-nine polymorphic products identified $66.1 \%$ of the samples by unique RAPD multilocus profiles. A cluster analysis grouped the samples into two broad groups corresponding to northern or southern provenances. AMOVA analysis showed that only $17.7 \%$ of the genetic diversity was partitioned within populations. These results are in contrast to data available for
\end{abstract}

other Antirrhinum species. This genetic structure could be explained by the predominant selfing behaviour exhibited by A. subbaeticum as opposed to the allogamy of other congeners. Genetic diversity within populations does not seem to be strongly related to population size and historical factors could be responsible for the very low levels of genetic diversity found in one population. Given the low genetic diversity within populations, it is suggested that an extensive sampling of individuals be made for recovering appropriate levels of the gene pool for ex situ preservation. However, translocation of individuals to the genetically weakened Bogarra population from other sources is not recommended.

Heredity (2002) 89, 387-393. doi:10.1038/sj.hdy.6800157

Keywords: Antirrhinum; conservation genetics; intraspecific variation; endangered species; Mediterranean flora; rupicolous plants

\section{Introduction}

Reliable management of rare and endangered plant taxa for conservation is refined by the genetic evaluation of their extant populations. The loss of genetic variability is predicted to have a negative influence on the capacity of a species to withstand stochastically-induced environmental changes (Ellstrand and Elam, 1993). Accordingly, in order to devise management strategies, conservation studies should take into account not only the levels of genetic variation present within and among populations but how they are partitioned (Hamrick, 1983; Holsinger and Gottlieb, 1991; Ellstrand and Elam, 1993). This knowledge is crucial for those plants having a low effective population size and a fragmented habitat, since the effects of genetic drift and inbreeding depression may have a noteworthy influence on the concomitant genetic impoverishment of the species (Foré and Guttman, 1999). Unfortunately, predicting the levels of genetic diversity present (and how they are structured) in rare plants on the basis of geographic, ecological, life-history, reproductive and demographic features is often not reliable

JA Rosselló. Jardín Botánico, Universidad de Valencia, c/Quart 80, E46008, Valencia, Spain. E-mail: rossello@uv.es

Received 4 October 2001; accepted 30 June 2002
(Gitzendanner and Soltis, 2000) and empirical data are needed to improve conservation policies.

The Mediterranean Basin is one of the hotspots of biodiversity urging conservation priorities (Myers et al, 2000). Some 24000 wild taxa are estimated to grow in this area, and nearly $38 \%$ of them are narrow endemics. In addition, about $15 \%$ of the Mediterranean flora is endangered and about 30 taxa are documented to be extinct. Surprisingly, molecular data concerning genetic variability is available for fewer than 50 Mediterranean taxa (Rosselló, unpublished data).

Snapdragons (Antirrhinum sp, Scrophulariaceae) are a group of perennial plants inhabiting the western Mediterranean basin and most of the diversity of the genus is found in the Iberian Peninsula. With the exception of the A. majus group, the taxa are rupicolous, usually showing a restricted distribution, with few individuals distributed within fragmented populations. One of the most endangered snapdragons is $A$. subbaeticum, a narrow endemic taxon of SE Spain (Güemes et al, 1994); to date, only four populations are known (Figure 1, Table 1). SánchezGómez et al (1997) estimated that the known number of individuals was about 1000 . However, a drastic reduction in the number of plants was later noticed in three of the four known locations where almost all the individuals in accessible places had been eliminated due to abusive herbarium collecting and grazing pressure (Sánchez-Gómez, unpublished data). A decrease of more than $50 \%$ of indi- 


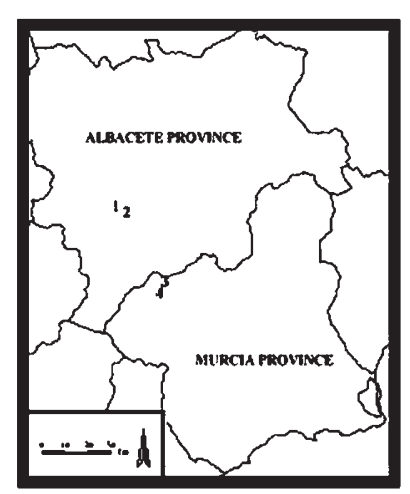

Figure 1 Location of the sampled populations of Antirrhinum subbaeticum. Population sites are located in the southeast of the Iberian peninsula and they are referred to as Bogarra (1), Potiche (2), Benizar (3) and Hondares (4).

Table 1 Location of populations of Antirrhinum subbaeticum, population size and number of plants sampled. Population size for Hondares is an estimate since a large proportion of the individuals are inaccessible

\begin{tabular}{lcc}
\hline Populations & Situation & $\begin{array}{c}\text { Population size (sampled } \\
\text { individuals) }\end{array}$ \\
\hline Bogarra (BO) & $38^{\circ} 34^{\prime} \mathrm{N}-2^{\circ} 14^{\prime} \mathrm{W}$ & $31(10)$ \\
Potiche (PT) & $38^{\circ} 33^{\prime} \mathrm{N}-2^{\circ} 10^{\prime} \mathrm{W}$ & $103(15)$ \\
Benizar (MO) & $38^{\circ} 15^{\prime} \mathrm{N}-1^{\circ} 59^{\prime} \mathrm{W}$ & $25(18)$ \\
Hondares (AR) & $38^{\circ} 13^{\prime} \mathrm{N}-1^{\circ} 59^{\prime} \mathrm{W}$ & $250(10)$ \\
\hline
\end{tabular}

viduals has been noticed in the last 3 years, and about 400 plants are currently known. The fragmented habitat, the small number of known populations, and the decline of population sizes makes $A$. subbaeticum a priority species in which to develop management strategies.

Different molecular methods can be efficiently used to study the gene pool of rare species. Nevertheless, for practical reasons, RAPD (random amplified polymorphic DNA; Williams et al, 1990) markers have been frequently used to determine the genetic variability of endangered, relict and/or endemic taxa (eg Stewart and Porter, 1995; Bauert et al, 1998; Liao and Hsiao, 1998; Las Heras et al, 1999; Maki and Horie, 1999). In this paper, the RAPD technique is applied to A. subbaeticum; more specifically, the following questions are addressed: (a) are levels of genetic variation present in this species similar to those reported in congeneric taxa?; (b) what sampling strategy is necessary to maximize the capture of genetic variation for ex-situ (seed bank) preservation?; and (c) is genetic variation structured in such a way that translocation of individuals among populations could be useful for population reinforcement?

\section{Materials and methods}

\section{Plant sampling}

Antirrhinum subbaeticum mostly lives in inaccessible rocky places and calcareous overhangs. Therefore, the sampling strategy was constrained to collecting every accessible plant in each site. A total of 53 individuals were sampled for DNA typing (Table 1), and the number of accessions used is of the same order of magnitude as those used in similar works devoted to the genetic variability of rare plants (eg Martin et al, 1997; Morden and Loeffler, 1999).

\section{DNA isolation and PCR amplification}

DNA was extracted from young shoots of freshly collected samples to ensure good yield and DNA quality (Sytsma et al, 1993). A Quiagen Dnaeasy Plant mini Kit (Quiagen, Germany) was used to extract the DNA. RAPD reactions were performed in $25 \mu \mathrm{l}$, containing $10 \mathrm{mM}$

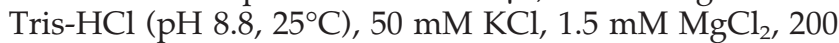
$\mu \mathrm{M}$ of each dATP, dCTP, dGTP and dTTP, $15 \mathrm{ng}$ primer, approximately $25 \mathrm{ng}$ genomic DNA and one unit of Taq polymerase. A control, containing all components except genomic DNA, was included in each set of reactions to prove that no contamination occurred. Amplifications were carried out in an Eppendorf Thermocycler under the following conditions: an initial cycle at $94^{\circ} \mathrm{C}$ for 2 min; 39 cycles of $30 \mathrm{sec}$ at $94^{\circ} \mathrm{C}, 30 \mathrm{sec}$ at $36^{\circ} \mathrm{C}, 1 \mathrm{~min}$ at $72^{\circ} \mathrm{C}$. A final cycle at $72^{\circ} \mathrm{C}$ for $10 \mathrm{~min}$ was included. Ten RAPD primers were used (Table 2 ). These were the same as those used by Torres (1999) after testing 60 different primers for a study of $A$. microphyllum, a related taxon belonging to the same subsection of the genus. Duplicate amplifications were conducted for each sample in order to ensure reproducible results and minimize errors. Bands which could not be reproduced in both assays were not considered for analysis. Amplification products were run on vertical $9 \%$ polyacrylamide gels in TBE buffer, stained using silver nitrate (Milligan, 1992) and viewed under visible light.

\section{Data analysis}

Gels were scanned and fragment sizes were determined by comparison with molecular weight standards (Roche, Germany) using the SIGMAGEL program (Jardel Scientific). The presence or absence of each RAPD fragment was treated as a binary character (coded 1 and 0 respectively) and used to construct the original data matrix. Bands showing the same gel mobilities were assumed to be homologous. No attempts were made to examine DNA homology of co-migrating bands by means of restriction endonucleases (Rieseberg, 1996) or using the amplified RAPD fragment as probes in blots of genomic DNA (Hadrys et al, 1992). We followed suggestions by Grosberg et al (1996) and no attempts were made to code for band intensity. Phenetic similarity was analysed by classification techniques (Clustering analysis) that were applied to a similarity matrix constructed using the Dice coefficient (Dice, 1945) by the RAPD DISTANCE program (Armstrong et al, 1994). The Dice coefficient calculates similarities on the basis of shared presence of a RAPD band, and exclude shared absence of fragments from the analysis. The unweighted pair group method (UPGMA) algorithm was used to construct phenograms.

Shannon's index (Shannon and Weaver, 1949) was used to describe the genetic diversity of the populations studied. This index is expressed as $H_{o}=-\Sigma p_{i} \log _{2} p_{i}$, where $p_{i}$ is the frequency of each amplification product. The parameters $H_{\text {pop }}$ (average diversity within populations) and $H_{s p}$ (the diversity within species) were also estimated. The analysis of molecular variance (AMOVA; Excoffier et al, 1992) using RAPD data is feasible when the RAPD phenotype is treated as a haplotype (Huff et al, 1993). Therefore, the AMOVA analysis was 
Table 2 Number of RAPD loci, primer sequence, amplified polymorphic fragments and phenotypes generated by 10 arbitrary primers

\begin{tabular}{|c|c|c|c|c|c|c|c|c|c|c|c|c|}
\hline \multirow[t]{2}{*}{ PRIMER } & \multirow[t]{2}{*}{ Nucleotide sequence } & \multirow{2}{*}{$\begin{array}{c}\text { Fragment size } \\
\text { range }\end{array}$} & \multirow{2}{*}{$\begin{array}{l}\text { No. loci ( } \% \\
\text { polymorphic) }\end{array}$} & \multicolumn{4}{|c|}{ Polymorphic bands } & \multirow{2}{*}{$\begin{array}{c}\text { No. } \\
\text { phenotypes }\end{array}$} & \multicolumn{4}{|c|}{ Phenotypes } \\
\hline & & & & Bo & $P t$ & $A r$ & Mo & & Bo & $P t$ & $A r$ & Mo \\
\hline UBC-507 & AGA CGT ACT C & $200-1350$ & $6(16,6)$ & 0 & 0 & 0 & 0 & 2 & 1(a) & 1(a) & 1(b) & 1(a) \\
\hline UBC-511 & GAA TGG TGA G & $200-2200$ & $8(37,5)$ & 0 & 1 & 0 & 0 & 3 & 1(a) & $2(a, b)$ & $1(\mathrm{c})$ & $1(\mathrm{c})$ \\
\hline UBC-514 & CGG TTA GAC G & $411-2500$ & $10(50,0)$ & 1 & 2 & 1 & 2 & 7 & $2(a, b)$ & $3(c, d, e)$ & $2(a, f)$ & $3(a, b, g)$ \\
\hline UBC-523 & ACA GGC AGA C & $290-2215$ & $15(53,3)$ & 0 & 0 & 2 & 2 & 6 & $1(\mathrm{a})$ & 1(b) & $2(\mathrm{c}, \mathrm{d})$ & $3(c, e, f)$ \\
\hline UBC-536 & GCC CCT CGT C & $588-1670$ & $9(22,2)$ & 0 & 1 & 0 & 1 & 4 & 1(a) & $2(a, b)$ & 1(a) & $2(c, d)$ \\
\hline UBC-540 & CGG ACC GCG T & $465-2214$ & $11(45,5)$ & 0 & 3 & 0 & 2 & 9 & 1(a) & $5(\mathrm{~b}, \mathrm{c}, \mathrm{d}, \mathrm{e}, \mathrm{f})$ & $1(\mathrm{~g})$ & $3(\mathrm{~g}, \mathrm{~h}, \mathrm{i})$ \\
\hline UBC-543 & CGC TTC GGG T & $348-2543$ & $12(50,0)$ & 0 & 0 & 1 & 4 & 9 & 1(a) & 1(b) & $2(c, d)$ & $5(\mathrm{e}, \mathrm{f}, \mathrm{g}, \mathrm{h}, \mathrm{i})$ \\
\hline UBC-557 & GTG TAG AGC C & $506-2178$ & $6(16,6)$ & 0 & 0 & 1 & 0 & 2 & 1(a) & 1(a) & $2(a, b)$ & 1(a) \\
\hline OP-O01 & GGC ACG TAA G & $364-2154$ & $9(44,4)$ & 0 & 0 & 1 & 3 & 4 & 1(a) & 1(a) & $2(a, b)$ & $3(\mathrm{a}, \mathrm{c}, \mathrm{d})$ \\
\hline OP-O20 & ACA CAC GCT G & $480-1864$ & $7(57,1)$ & 0 & 4 & 2 & 0 & 6 & 1(a) & $5(a, b, c, d, e)$ & $3(a, e, f)$ & 1(a) \\
\hline
\end{tabular}

conducted to estimate variance components at several hierarchical levels, partitioning the variation among geographical groups, among populations and among individuals within populations. Populations were assigned a northern (Bogarra and Potiche) or southern provenance (Benizar and Hondares). Since RAPD markers are generally dominant, for the estimation of population genetic structure we made (perhaps unrealistic) assumptions that null bands are homologous and that populations are in Hardy-Weinberg equilibrium (Lynch and Milligan, 1994). AMOVA analyses were undertaken with the program ARLEQUIN 1.1 (Schneider et al, 1997).

\section{Results}

A total of 93 reproducible RAPD bands were obtained with 10 primers (Table 2). Of those, 54 fragments $(58.1 \%$ ) were shared by all individuals, whereas 39 RAPD bands $(41.9 \%)$ were polymorphic. $8.6 \%$ of amplified fragments were restricted to single individuals. Seven RAPD markers showed a marked geographic component of variation. Thus, four fragments (UBC-511 200 bp, UBC-523 $360 \mathrm{bp}$, UBC-523 $560 \mathrm{bp}$, and UBC-523 $2150 \mathrm{bp}$ ) were fixed for the Bogarra and Potiche populations, and absent from Benizar and Hondares. Conversely, three bands fixed in the Benizar and Hondares populations (UBC-511 $450 \mathrm{bp}$, UBC-523 $460 \mathrm{bp}$, UBC-540 $2200 \mathrm{bp}$ ) were absent in the other populations. Despite the presence of these population markers, similarity values within populations were remarkably high (range of mean values: 0.975-0.997), and overall similarity between $A$. subbaeticum individuals ranged from 0.848 to 1 (mean: 0.934). Composite RAPD profiles showed only two phenotypes in Bogarra population, whereas in the geographycally close Potiche population 14 composite phenotypes were detected. This implies that all but one individual from this site could be discriminated by their RAPD profile.

The cluster phenogram obtained by the UPGMA algorithm divided the populations of $A$. subbaeticum into two main groups (Figure 2); one comprised the northern populations (Bogarra and Potiche) and the other the southern ones (Benizar and Hondares).

Genetic diversity values within populations $\left(H_{o}\right)$ were calculated for primers that produced polymorphic bands (Table 3). Bogarra showed the lowest within population diversity $\left(H_{o}=0.036\right)$, whereas Potiche $\left(H_{o}=0.335\right)$ and Benizar $\left(H_{o}=0.344\right)$ were the most diverse. Mean diver-

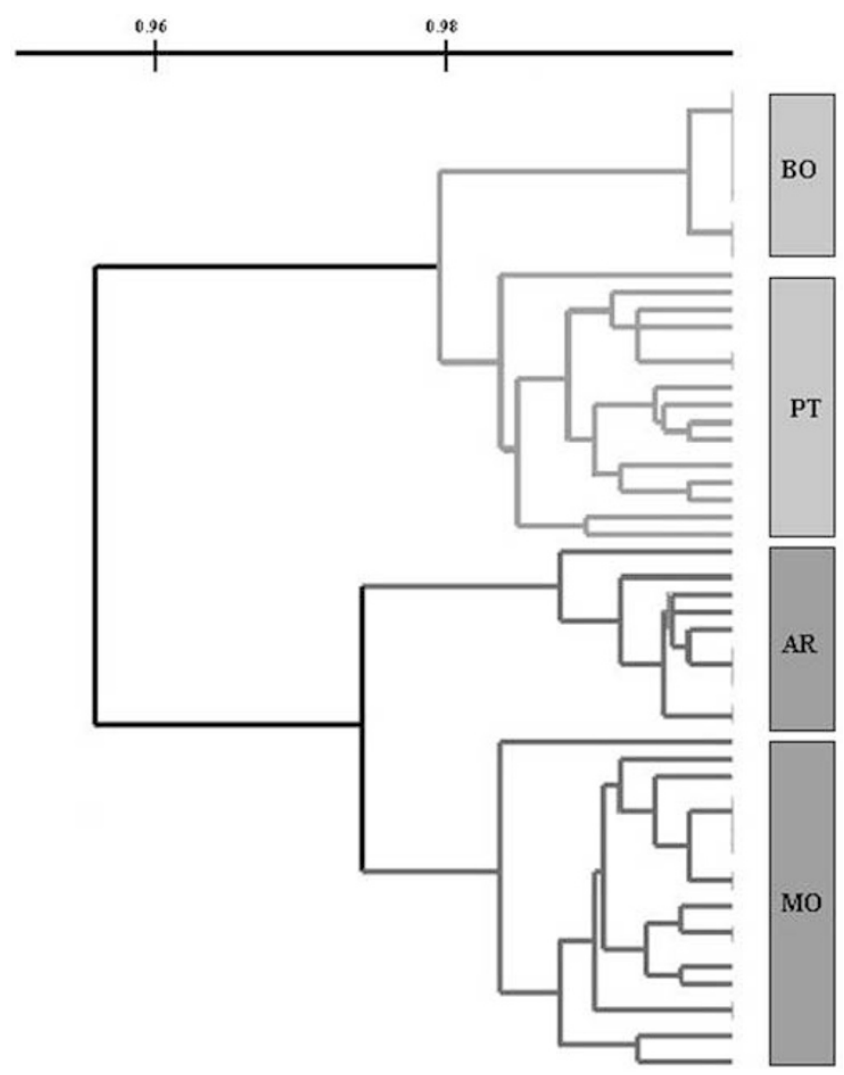

Figure 2 Dendrogram showing similarities among Antirrhinum samples based on RAPD data from 10 primers. Similarity matrix was calculated using Dice coefficient; the phenogram was build according to the unweighted pair-group method with arithmetic mean (UPGMA). Population codes: Bogarra (BO), Potiche (PT), Benizar (MO), and Hondares (AR).

sity within the species $\left(H_{s p}\right)$ was 1.008 , a value significantly higher (ANOVA, $F=9.06, P=0.008$ ) than the mean value obtained within the populations $\left(H_{\text {pop }}=0.237\right)$.

Fixation indexes among pairs of populations are shown in Table 4. High $F_{\mathrm{ST}}$ values were found between the two population pairs, namely Bogarra-Potiche and BenizarHondares. AMOVA showed that the greatest variation percentage $(46.8 \%)$ was attributable to regional differences (northern vs southern populations). Between-population within region divergence accounted for $35.5 \%$ of 
Table 3 Estimates of the genetic diversity within and between populations of Antirrhinum subbaeticum generated by 10 random primers

\begin{tabular}{|c|c|c|c|c|c|c|}
\hline \multirow[t]{2}{*}{ Primer } & \multicolumn{4}{|c|}{$H_{o}$} & \multirow[t]{2}{*}{$H_{p o p}$} & \multirow[t]{2}{*}{$H_{s p}$} \\
\hline & $B O$ & $P T$ & $M O$ & $A R$ & & \\
\hline UBC-507 & 0.000 & 0.000 & 0.000 & 0.000 & 0.000 & 0.311 \\
\hline UBC-511 & 0.000 & 0.388 & 0.000 & 0.000 & 0.097 & 1.164 \\
\hline UBC-514 & 0.360 & 0.507 & 0.514 & 0.332 & 0.428 & 0.832 \\
\hline UBC-523 & 0.000 & 0.000 & 0.383 & 0.469 & 0.213 & 2.527 \\
\hline UBC-536 & 0.000 & 0.328 & 0.232 & 0.000 & 0.140 & 0.461 \\
\hline UBC-540 & 0.000 & 1.129 & 0.430 & 0.000 & 0.390 & 1.636 \\
\hline UBC-543 & 0.000 & 0.000 & 1.272 & 0.332 & 0.401 & 1.966 \\
\hline UBC-557 & 0.000 & 0.000 & 0.000 & 0.332 & 0.083 & 0.133 \\
\hline Op-O01 & 0.000 & 0.000 & 0.614 & 0.464 & 0.270 & 0.427 \\
\hline $\mathrm{Op}-\mathrm{O} 20$ & 0.000 & 0.998 & 0.000 & 0.394 & 0.348 & 0.630 \\
\hline Mean \pm s.d. & $0.036 \pm 0.02$ & $0.335 \pm 0.10$ & $0.344 \pm 0.08$ & $0.232 \pm 0.07$ & 0.237 & 1.008 \\
\hline
\end{tabular}

$H_{o}=$ diversity within populations; $H_{p o p}=$ average diversity within populations; $H_{s p}=$ diversity within species; $H_{p o p} / H_{s p}=$ proportion of diversity within populations; $\left(H_{s p}-H_{p o p}\right) / H_{s p}=$ proportion of diversity among populations. $\mathrm{BO}=\mathrm{Bogarra}$; $\mathrm{PT}=\mathrm{Potiche}$; MO= Benizar; $\mathrm{AR}=$ Hondares.

Table 4 Estimates of fixation indexes $\left(F_{\mathrm{ST}}\right)$ between pairs of populations of Antirrhinum subbaeticum. $F_{\mathrm{ST}}$ values are all significant at the $P<0.001$ level

\begin{tabular}{lccc}
\hline & BO & $P T$ & $M O$ \\
\hline BO & & & \\
PT & 0.64231 & & \\
MO & 0.82742 & 0.76865 & 0.68610 \\
AR & 0.91061 & 0.82922 & 0.06 \\
\hline
\end{tabular}

$\mathrm{BO}=$ Bogarra; $\mathrm{PT}=$ Potiche; $\mathrm{MO}=$ Benizar; $\mathrm{AR}=$ Hondares

the genetic diversity, whereas within population variation contributed only $17.7 \%$ (Table 5), which suggested a genetic isolation of the populations.

\section{Discussion}

Antirrhinum subbaeticum is a Spanish endemic snapdragon which has shown a dramatic decline in population sizes in very recent years. Patterns of genetic diversity using RAPD markers have shown that: (i) the majority of RAPD variation detected was partitioned

Table 5 Analysis of molecular variance (AMOVA) for 53 individuals of Antirrhinum subbaeticum using 39 polymorphic RAPD markers. Northern populations, Bogarra and Potiche; southern populations, Benizar and Hondares. Statistics include mean squared deviations (MSD), variance component estimates, the percentage of the total variance contributed by each component and the probability of obtaining a more extreme component estimate by chance alone (calculated after 10000 permutations)

\begin{tabular}{lrrrrcc}
\hline Source of variation & d.f. & MSD & $\begin{array}{c}\text { Variance } \\
\text { component }\end{array}$ & $\begin{array}{c}\% \text { total } \\
\text { variance }\end{array}$ & $P$ \\
\hline $\begin{array}{l}\text { Northern vs } \\
\begin{array}{l}\text { southern } \\
\text { populations }\end{array}\end{array}$ & 1 & 122.22 & 3.26537 & 46.76 & $<0.0001$ \\
$\begin{array}{l}\text { Among } \\
\text { populations }\end{array}$ & 2 & 64.08 & 2.47854 & 35.49 & $<0.0001$ \\
$\begin{array}{l}\text { Within populations } \\
\text { Total }\end{array}$ & 49 & 60.71 & 1.23900 & 17.74 & $<0.0001$ \\
& 52 & 247.01 & 6.98291 & 99.99 & $<0.0001$ \\
\hline
\end{tabular}

between populations; (ii) many individuals in some populations shared multi-locus banding phenotypes; and (iii) a cluster analysis grouped the samples into two geographic groups corresponding to northern or southern accessions.

\section{Genetic diversity within Antirrhinum species}

Antirrhinum majus is a classical model system for floral development, for which the genetic control of organ morphogenesis has been extensively studied (Theissen and Saedler, 1999). However, relatively few data concerning the genetic diversity of wild relatives have been gained (Table 6). This is unfortunate given the high number of endangered Antirrhinum taxa showing fragmented populations and for which conservation strategies have not been yet devised. Within Antirrhinum, the overall pattern which emerges through the analysis of genetic data obtained from allozyme electrophoresis and RAPD fingerprinting (Mateu-Andrés, 1999; Torres, 1999; MateuAndrés and Segarra-Moragues, 2000) is that snapdragon species, even the most restricted ones, are by no means genetically impoverished. Thus, the proportion of polymorphic allozymic loci for most of the studied populations reaches, and in some instances exceeds, 50\%, and $75 \%$ of populations have an average number of two or more alleles per locus. A third descriptor of genetic diversity, the average percentage of expected heterozygotes, also corroborates the view that, overall, genetic variation present within Antirrhinum species has not been substantially depleted by stochastic factors, such genetic drift or population bottlenecks.

DNA-based methods have shown slightly different patterns of genetic variation for two narrowly distributed species in the Iberian Peninsula, A. microphyllum and $A$. subbaeticum. These results are highly comparable since both studies were based on the same set of amplification primers. A moderate (A. subbaeticum, 41.9\%; this study) to high (A. microphyllum, 90\%; Torres, 19991) proportion of polymorphic amplified products were detected in both species. In fact, multilocus phenotypes allowed the discrimination of all but one of 184 analysed individuals of A. microphyllum, whereas only $66.1 \%$ of the A. subbaeticum samples displayed unique RAPD profiles. Antirrhinum microphyllum, like most other congener species for which 
Table 6 Summary of genetic diversity reported for Antirrhinum species

\begin{tabular}{|c|c|c|c|c|c|c|c|}
\hline & $\begin{array}{l}\text { Breeding } \\
\text { system }\end{array}$ & Marker & $H_{e}$ & $H_{t}$ & $H_{s}$ & $G_{s t}$ & Ref. \\
\hline A. lopesianum & SI & Allozymes & 0.257 & 0.193 & - & - & Mateu-Andrés (1999) \\
\hline A. mollissimum & SI & Allozymes & $0.148-0.260$ & 0.280 & 88.92 & 0.105 & Mateu-Andrés (1999) \\
\hline \multirow[t]{3}{*}{ A. microphyllum } & SI & Allozymes & $0.335-0.470$ & 0.520 & 96.53 & 0.043 & Mateu-Andrés (1999) \\
\hline & & Allozymes & $0.188-0.217$ & 0.219 & 94.06 & 0.026 & Torres (1999) \\
\hline & & RAPD & - & 1.50 & 83.16 & 0.119 & Torres (1999) \\
\hline A. charidemi & SI & Allozymes & $0.080-0.117$ & 0.103 & 91.45 & 0.054 & $\begin{array}{l}\text { Mateu-Andrés and Segarra- } \\
\text { Moragues (2000) }\end{array}$ \\
\hline A. valentinum & SI & Allozymes & $0.029-0.092$ & 0.178 & 38.36 & 0.481 & $\begin{array}{l}\text { Mateu-Andrés and Segarra- } \\
\text { Moragues (2000) }\end{array}$ \\
\hline A. subbaeticum & SC & RAPD & - & 1.00 & 17.74 & 0.822 & This work \\
\hline
\end{tabular}

SI = Self-incompatible, SC = Self-compatible, $H_{e}=$ expected heterozygotes (range of population averages), $H_{t}=$ total genetic diversity, $H_{s}$ = percentage of the genetic diversity explained by the within-population variation, $G_{s t}=$ coefficient of genetic differentiation. For RAPD data, $H_{t}$ was calculated from the Shannon's index (Shannon and Weaver, 1949) and is therefore not comparable to the values based on allozyme markers. Only a single population of $A$. lopesianum was analysed by Mateu-Andrés (1999) and accordingly no $H_{s}$ and $G_{s t}$ values were given.

the breeding system has been determined is self-incompatible (Torres, 1999; Güemes, unpublished data). Predictions from a large body of empirical data suggest that outcrossing species usually show higher genetic diversity than those showing a self-compatible reproductive system (Loveless and Hamrick, 1984; Hamrick et al, 1979, 1991). In addition, the former are expected to have a high percentage of the genetic diversity contained within populations (eg Huff et al, 1993; Martin et al, 1997, 1999; Gugerli et al, 1999), as compared to selfers which show the opposite pattern: low genetic within-population diversity and high population differentiation. Overall, these trends also apply to Antirrhinum (Table 6) and suggest that the knowledge of the breeding system could allow a reasonably good prediction of the genetic structure present within species.

The structure of the genetic diversity obtained for $A$. subbaeticum using RAPD data clearly differs from the other Antirrhinum species so far analysed with isozyme and RAPD markers, with the exception of $A$. valentinum, which is discussed below. Preliminary data on the breeding system of $A$. subbaeticum indicate that this species is predominantly self-compatible. Unmanipulated caged flowers in the field did not produce seeds, but artificial self-pollinations resulted in 80-90\% of fruit set (J Jiménez, unpublished data). Field observations of visitors and the crossing data suggest that geitonogamy is the predominant breeding system of this species. Antirrhinum valentinum has been reported to be self-incompatible (MateuAndrés and Segarra-Moragues, 2000) but no data concerning the breeding system of this species were given. In previous research, preliminary reproductive data for this taxon were not obtained in the field but from plants grown at the Botanical garden of Valencia originating from a single population. Furthermore, artificial pollinations did not include any test for geitonogamy. Accordingly, it is premature to exclude the possibility that wild $A$. valentinum populations are self-compatible. Until its description, $A$. subbaeticum was included within the variation of $A$. valentinum, to which it is most closely related (Güemes et al, 1994). In fact, in a phylogenetic study of Antirrhinum using morphological characters and ITS sequences, Vargas et al (unpublished data) found that $A$. valentinum and $A$. subbaeticum were sister taxa. The percentage of among-population differentiation obtained for A. valentinum (Mateu-Andrés and Segarra-Moragues, 2000) and $A$. subbaeticum (this study) using independent molecular markers is also highly similar (Table 6). These results for two sister taxa showing the same chasmophytic (and discontinuous) habitat, life history attributes (including flowering time), flower characteristics, and range of geographical distribution, but differing so conspicuously in their compatibility breeding systems are intriguing. Preliminary data on the genetic structure of A. valentinum using RAPD data indicated a substantially lower $F_{S t} t_{S T}$ value of $44.4 \%$ (Jiménez, unpublished data). Since Mateu-Andrés and Segarra-Moragues (2000) speculated that, in Antirrhinum, flowering time and habitat continuity could be good predictors for the distribution of the genetic variation among populations, further detailed work on the reproductive system of $A$. valentinum is imperative to support their hypothesis.

RAPD data obtained for $A$. subbaeticum indicate: (i) the lower overall genetic diversity compared to A. microphyllum; (ii) high population differentiation, in contrast to data available for several Antirrhinum species; and (iii) a higher percentage of individuals sharing multilocus phenotypes in A. subbaeticum than A. microphyllum.

\section{Implications of RAPD data for conservation management of the species}

According to Franklin (1980), the estimated minimum effective size of a population (not suffering serious inbreeding) needed to maintain sufficient genetic richness is 50 individuals, and 500 for a given population to counteract the effects of genetic drift. Since about 400 individuals are currently known for $A$. subbaeticum and the fact that two out of the four known populations have few individuals (about 30), a rapid impoverishment of the gene pool of the species should be expected. However, survival of endangered species may not necessarily be compromised by the absence of significant levels of genetic diversity, and low levels of genetic variation are not necessarily associated with low population viability (Arden and Lambert, 1997). Molecular data cannot prove that the low genetic variation present in some populations of $A$. subbaeticum is a cause of concern for its viability in the wild. By contrast, there is evidence that a 
drastic decline in population size occurred in recent times after its discovery and, in this way, demographic catastrophes may be a more imminent threat to this species.

RAPD data suggest that individuals within single populations are genetically very closely related (mean Dice similarity values higher than 97\%), but apparently there is not a strong significant relationship between population size and genetic diversity $(r=0.12, P<0.88)$. Thus, the smallest known population (Benizar) shows the highest within-population diversity (0.344). These results should be compared to those of Bogarra, which have a similar population size but showed the lowest genetic diversity (0.036). As acknowledged for the putative outcrosser Aconitum lycoctonum (Utelli et al, 1999), population size or mating system cannot be the main factors determining genetic structure in plants. This species, in spite of being adapted to pollination by long-tongued bumblebees, showed a genetic structure suggesting inbreeding in more than half of the populations, which could be better explained by historical causes related to hypothesized Pleistocene refugia. Bogarra population could be viewed as genetically impoverished through a long history of genetic drift from long-term small population size or a short-term population bottleneck, the RAPD data obtained being a mirror of the population decline. The alternative view that this population has recently been established by few propagules also matches the results obtained and cannot be ruled out. The chasmophytic habitat displayed by most Antirrhinum species is environmentally homogeneous and it is suggested to act as a refugium for plants believed to have a pre-Pleistocene origin (Davis, 1950; Runemark, 1969). Likewise, populations are not expected to have suffered drastic bottlenecks in the ancient past. The documented reduction of nearly $50 \%$ of the known number of individuals (Sánchez-Gómez et al, 1997) located in accessible places by direct or indirect anthropic pressures suggest that, by contrast, population decline could have occurred recurrently in the last 10000 years when human activity prompted the landscape turnover.

RAPD data suggest that for effective ex situ conservation of most of the genetic diversity found in A. subbaeticum through seed bank establishment, the following sampling strategies should be favoured: (i) all four populations and as many individuals as possible should be sampled within populations; (ii) one or a few capsules from each individual should be collected since this approach will efficiently recover most of the allelic diversity present in the seeds, and will not reduce the number of propagules to alter drastically the chance of seed germination and establishment within populations.

Without a detailed analysis to check for inbreeding depression, it is premature to suggest translocation of individuals from other sites to Bogarra as a useful recovery measure to enhance the gene pool of this population. Genetic typing of all individuals from Bogarra may reveal additional genotypes, and a crossing program between selected individuals displaying different RAPD phenotypes aimed at expanding the genetic variation of this population could be highly effective. Similar recovery strategies in a bottlenecked population of the highly endangered Trifolium amoenum (Knapp and Connors, 1999) revealed a high amount of polymorphism after few generations. Further, given the genetic differentiation among A. subbaeticum populations suggestive of a long history of reproductive isolation, there is the potential danger that adaptative differences between plants from separate origins may have developed. Accordingly, mixing locally adapted genotypes could result in outbreeding depression. Nevertheless, if translocation actions are to be prioritised by administration recovery programs, this should be made by selecting the closest geographical population to the propagule source, that is from Potiche, as the nearer the populations, the closer the genetic identities.

\section{Acknowledgements}

The authors thank G Nieto-Feliner for his helpful comments on the manuscript. This work has been supported by funds of the DGICYT project PB97-1061 to P Sánchez-Gómez.

\section{References}

Arden SL, Lambert DM (1997). Is the black robin in genetic peril? Mol Ecol 6: 21-28.

Armstrong JS, Gibbs AJ, Peakall R, Weiller G (1994). The RAPDistance Package. ftp: //life.anu.edu.au/pub/software/ RAPDistance.

Bauert MR, Kälin M, Baltisberger M, Edwards PJ (1998). No genetic variation detected within isolated relict populations of Saxifraga cernua in the Alps using RAPD markers. Mol Ecol 7: 1519-1527.

Davis PH (1950). Cliff vegetation in the eastern Mediterranean. J Ecol 39: 63-93.

Dice LR (1945). Measures of the amount of ecologic association between species. Ecology 26: 297-302.

Ellstrand NC, Elam DR (1993). Population genetic consequences of small population size: implications for plant conservation. Ann Rev Ecol Syst 24: 217-242.

Excoffier L, Smouse PE, Quattro JM (1992). Analysis of molecular variance inferred from metric distances among DNA haplotypes: application to human mitochondiral DNA restriction data. Genetics 131: 479-491.

Foré SA, Guttman SI (1999). Genetic structure of Helianthus occidentalis (Asteraceae) in a preserve with fragmented habitat. Am J Bot 86: 988-995.

Franklin IR (1980). Evolutionary change in small populations. In: Soulé ME, Wilcox B (eds) Conservation Biology: An evolutionary-ecological perspective, Sinauer Associates: Sunderland, pp 135-149.

Gitzendanner MA, Soltis PS (2000). Patterns of genetic variation in rare and widespread plant congeners. Am J Bot 87: 783-792.

Güemes J, Mateu I, Sánchez-Gómez P (1994). Antirrhinum subbaeticum Güemes, Mateu \& Sánchez Gómez (Scrophulariaceae), especie nueva de la Penánsula Ibérica. Anales Jard Bot Madrid 51: 237-247.

Grosberg RK, Levitan DR, Cameron B (1996). Characterization of genetic structure and genealogies using RAPD-PCR markers: a random primer for the novice and nervous. In: Ferraris J, Palumbi SR (eds) Molecular Zoology. Advances, strategies, and protocols, Wiley-Liss: New York, pp 67-100.

Gugerli F, Eichenberger K, Schneller JJ (1999). Promiscuity in populations of the cushion plant Saxifraga oppositifolia in the Swiss Alps as inferred from random amplified polymorphic DNA (RAPD). Mol Ecol 8: 453-461.

Hadrys H, Balick M, Schierwater B (1992). Applications of random amplified polymorphic DNA (RAPD) in molecular ecology. Mol Ecol 1: 55-63.

Hamrick JL (1983). The distribution of genetic variation within and among natural plant populations. In: Schonewald-Cox CM, Chambers SM, MacBryde B, Thomas WL (eds) Genetics and Conservation, Benjamin-Cummings: California, pp 335348 . 
Hamrick JL, Godt MJW, Murawski DA, Loveless MD (1991). Correlations between species traits and allozyme diversity: implications for conservation biology. In: Falk DA, Holsinger KE (eds) Genetics and Conservation of Rare Plants, Oxford University Press: New York, pp 75-86.

Hamrick JL, Linhart YB, Mitton JB (1979). Relationships between life history characteristics and electrophoretically detectable genetic variation in plants. Ann Rev Ecol Syst 10: 173-200.

Holsinger KE, Gottlieb LD (1991). Conservation of rare and endangered plants: principles and prospects. In: Falk DA, Holsinger KE (eds) Genetics and Conservation of Rare Plants, Oxford University Press: New York, pp 195-208.

Huff DR, Peakall R, Smouse PE (1993). RAPD variation within and among natural populations of outcrossing buffalograss (Buchloë dactyloides (Nutt.) Engelm.). Theor Appl Genet 86: 927-934.

Knapp EE, Connors PG (1999). Genetic consequences of a singlefounder population bottleneck in Trifolium amoenum (Fabaceae). Am J Bot 86: 124-130.

Las Heras J, Gómez-Mercado F, Guil JL, Rodríguez-García I, García-Maroto F (1999). Genetic relationships and population structure within taxa of the endemic Sideritis pusilla (Lamiaceae) assessed using RAPDs. Bot J Linn Soc 129: 345358.

Liao LC, Hsiao JY (1998). Relationship between population genetic structure and riparian habitat as revealed by RAPD analysis of the rheophyte Acorus gramineus Soland. (Araceae) in Taiwan. Mol Ecol 7: 1275-1281.

Loveless MD, Hamrick JL (1984). Ecological determinants of genetic structure in plant populations. Ann Rev Ecol Syst 16 447-479.

Lynch M, Milligan BG (1994). Analysis of population genetic structure with RAPD markers. Mol Ecol 3: 91-99.

Maki M, Horie S (1999). Random amplified polymorphic DNA (RAPD) markers reveal less genetic variation in the endangered plant Cerastium fischerianum var. molle than in the widespread conspecific C. fischerianum var. fischerianum (Caryophyllaceae). Mol Ecol 8: 145-150.

Martin C, González-Benito ME, Iriondo JM (1997). Genetic diversity within and among populations of a threatened species: Erodium paularense Fern. Gonz. \& Izco. Mol Ecol 6: 813-820.

Martin C, González-Benito ME, Iriondo JM (1999). The use of genetic markers in the identification and characterization of three recently discovered populations of a threatened plant species. Mol Ecol 8: S31-S40.

Mateu-Andrés I (1999). Allozymic variation and divergence in three species of Antirrhinum L. (ScrophulariaceaeAntirrhineae). Bot J Linn Soc 131: 187-199.
Mateu-Andrés I, Segarra-Moragues JG (2000). Population subdivision and genetic diversity in two narrow endemics of Antirrhinum L. Mol Ecol 9: 2081-2087.

Milligan BG (1992). Plant DNA isolation. In: Hoelzel AR (ed) Molecular Genetic Analysis of Populations: a practical approach, IRL Press: Oxford, pp 59-88.

Morden CW, Loeffler W (1999). Fragmentation and genetic differentation among subpopulations of the endangered Hawaiian mint Haplostachys haplostachya (Lamiaceae). Mol Ecol 8: 617-625.

Myers N, Mittermeier RA, Mittermeier CG, Da Fonseca GAB, Kent J (2000). Biodiversity hotspots for conservation priorities. Nature 403: 853-858.

Rieseberg LH (1996). Homology among RAPD fragments in interspecific comparisons. Mol Ecol 5: 99-105.

Runemark H (1969). Reproductive drift, a neglected principle in reproductive biology. Bot Not 122: 90-129.

Sánchez-Gómez P, Güemes J, Herranz JM, Fernández S, López G, Martínez JJ (1997). Plantas vasculares endémicas, amenazadas o raras de la provincia de Albacete. Instituto de estudios albacetenses de la Excma. Diputación de Albacete: Albacete.

Schneider S, Kueffer JM, Roessli D, Excoffier L (1997). Arlequin v. 1.1: A software for population genetic data analysis. Genetics and Biometry Laboratory, University of Geneva: Switzerland.

Shannon CE, Weaver W (1949). The Mathematical Theory of Communication. University of Illinois Press: Urbana.

Stewart CN, Porter DM (1995). RAPD profiling in biological conservation: an application to estimating clonal variation in rare and endangered Iliamna in Virginia. Biol Conserv 74: 135-142.

Sytsma KJ, Givnish TJ, Smith JF, Hahn WJ (1993). Collection and storage of land plant samples for macromolecular comparisons. Methods in Enzymol 224: 23-37.

Theissen G, Saedler H (1999). The golden decade of molecular floral development (1990-1999): a cheerful obituary. Develop Genet 2: 181-193.

Torres ME (1999). Estudios de la autoecología, biología reproductiva y estructura genética de Antirrhinum microphyllum Rothmaler (Scrophulariaceae). Evaluación de su estado de conservación. MSc Thesis, University Autónoma, Madrid.

Utelli AB, Roy BA, Baltisberger M (1999). History can be more important than 'pollination syndrome' in determining the genetic structure of plant populations: the case study of Aconitum lycoctonum. Heredity 82: 574-584.

Williams JGK, Kubelik AR, Livak K, Rafalski JA, Tingey SV (1990). DNA polymorphisms amplified by arbitrary primers are useful as genetic markers. Nucl Acids Res 18: 6531-6535. 